\title{
INFLUENCE OF SILICONE CARBIDE ADDITIONS ON THE MECHANICAL PROPERTIES OF CONCRETE
}

\author{
VPLIV DODATKOV SILICIJEVEGA KARBIDA NA LASTNOSTI \\ BETONA
}

\author{
Marcin Małek*, Mateusz Jackowski, Wojciech Życiński, Waldemar Lasica, \\ Mariusz Owczarek \\ Military University of Technology in Warsaw, Faculty of Civil Engineering and Geodesy, 2 gen. Sylwestra Kaliskiego Street, 00-908 Warsaw, \\ Poland
}

Prejem rokopisa - received: 2019-07-25; sprejem za objavo - accepted for publication: 2020-05-02

\author{
doi: $10.17222 / \mathrm{mit} .2019 .173$
}

\begin{abstract}
In this work, the results of the chemical modification of concrete based on Portland cement by a silicon carbide F140 addition of $(5,10$ and 15$) w / \%$ to the mixture as a filler are summarized. The main goal of this study was to characterize the influence and $w / \%$ of content addition of new commercial fillers on the concrete's mechanical strength. A three-equation method for the reference recipe calculation is widely used. The process of concrete production including the white Portland cement ( $42.5 \mathrm{MPa}$ ), basalt aggregate, water and deflocculant based on polycarboxylate according to the calculated recipe. To characterize the basic properties of the studied concrete, SEM and LM observations, the chemical composition, and a slump cone test were investigated. The thermal properties were also investigated using a thermal analyser. The samples of concrete were characterized by compressive strength and bending tests after $28 \mathrm{~d}$ of curing. The results were compared with reference samples of concrete without the chemical addition of the silicon carbide. This study proved that all the chosen modifications had an increased effect on the final mechanical strength of the researched concrete samples. The thermal conductivity was also increasing. These kinds of concretes are very promising for applications in civil engineering and new building technologies of the future.

Keywords: silicon carbide, concrete modification, mechanical strength, thermal properties
\end{abstract}

V članku avtorji predstavljajo rezultate kemične modifikacije betona na osnovi Portland cementa $\mathrm{z}$ dodatkom $(5,10$ in 15$)$ w/\% silicijevega karbida F140 v betonsko mešanico. Glavni cilj študije je bil določiti vpliv dodatka novega komercialnega polnila in njegove vsebnosti na mehansko trdnost betona. Uporabili so tri enačbe za referenčni izračun recepture. Postopek izdelave betona je vključeval uporabo belega Portland cementa (42,5 MPa), bazaltnih agregatov, vode in deflokulanta na osnovi polikarboksilata v skladu z izračunom recepture. Karakterizacijo osnovnih lastnosti izdelanih betonov so sestavljale: metalografske analize z vrstičnim elektronskim (SEM) in optičnim mikroskopom (LM), določitev kemijske sestave in preizkus posedanja prisekanega stožca (t.i.: slump cone test). Prav tako so avtorji določili termične lastnosti betonov s termičnim analizatorjem ter mehansko tlačno in upogibno trdnost betonov po 28 dneh postopka utrjevanja. Rezultate so primerjali z referenčnim betonom brez dodatka silicijevega karbida. S študijo so avtorji pokazali, da vse izbrane modifikacije izboljšajo končno mehansko trdnost betona. Toplotna prevodnost betonov je prav tako narasla. Ta vrsta betonov je zelo perspektivna za uporabo v gradbeništvu in za nove bodoče gradbene tehnologije.

Ključne besede: silicijev karbid, modifikacija betona, mehanska trdnost, termične lastnosti

\section{INTRODUCTION}

In view of its physical and mechanical properties, silicon carbide is one of the most promising materials used for a ceramic composite. Due to the high mechanical strength, hardness and resistance to thermal shocks, the application of this material in concrete can limit the thickness of the used layers for fabricated components that need a high thermal conductivity. This will considerably reduce the weight and production costs. ${ }^{1-2}$ Another important advantage is the thermal and electrical conductivity of silicon carbide ceramic composites. Compared to other concrete admixture materials, silicon carbide is characterized by a several times higher thermal conductivity. Because of the high thermal transfer, the concrete products can transfer more heat into the researched space. This promotes the fragmentation of the micro-

*Corresponding author's e-mail:

marcin.malek@wat.edu.pl (Marcin Małek) structure and hence an increase of the mechanical strength of the concrete products. ${ }^{3-5}$

Nowadays, in prefabrication technology, concrete processes are mostly automated, and many steps are carried out by industrial robots. The newly developed admixture can be used for production in automated lines. The maturing time of a single sample does not change, and the technology is very similar. This kind of admixture makes it possible to use it in all companies without any modification. ${ }^{6-9}$

The aim of this study was to investigate the influence of a silicon carbide addition on the properties of concrete based on Portland cement.

\section{EXPERIMENTAL PART}

\subsection{Materials}

The concrete mixtures were produced using silicon carbide $99 \mathrm{C}$ as an admixture with an amount of $(5,10$ 
and 15) $w / \%$ of cement was used. Additionally, to manufacture concrete mixture ballast aggregates, Portland cement $(42.5 \mathrm{MPa})$, tap water and deflocculant based on polycarboxylate were used. The amount of deflocculant used was in accordance with the manufacturer's instructions and amounted to $0.8 \%$ of cement content. The mixture was fabricated in a steel reactor with a mechanical mixer equipped. The new recipe was calculated using an iterative and experience method.

\subsection{Methodology}

The silicon carbide morphology was determined using a scanning electron microscope (SEM). The observations were carried out on powder samples placed on carbon films utilizing an acceleration voltage of $5 \mathrm{kV}$, using a secondary-electron detector. The grain size was characterized by a laser diffraction method. The purity of the investigated powder was measured using an X-ray fluorescent spectrometer.

The mixing process lasted for 5 min using a mechanical mixer with 100 rotations per minute, in laboratory conditions. After that, the concrete mixtures were transported into steel forms and left for the curing process of $28 \mathrm{~d}$.


Figure 1: SEM images of silicon carbide used as an admixture
The measurement of the mechanical properties, such as bending strength, tensile strength and compressive strength, was analysed by a mechanical machine on samples prepared according to EN 206-1: 2014.

Research was carried out by measuring the basic thermal parameters such as: thermal conductivity coefficient, specific hear per unit of volume and thermal diffusivity. Additionally, the samples after the mechanical tests were observed to obtain the correct time of mixing, the time of vibration and the arrangement of the aggregate and admixture particles using a transmission-reflection microscope.

For each test 20 samples were prepared and measured. The average values of the test are shown on the diagrams.

\section{RESULTS}

The morphology and surface of the researched silicon carbide referred to as 400\# on SEM images are presented in Figure 1.

The average particle size of the silicon carbide is equal $22.7 \mu \mathrm{m}$. The particles are irregular and exhibit sharp edges and smooth surfaces. The particles do not agglomerate. The XRD results showed that the purity of the silicon carbide is $98 \%$; the rest are the pollutants from the production process.

The basic properties of the fabricated concrete mixture are shown in Table $\mathbf{1 .}$

Table 1: Basic properties of cement-silicon carbide mortal

\begin{tabular}{|c|c|c|c|c|c|}
\hline Recipe & $\begin{array}{c}\text { Cone } \\
\text { fall } \\
(\mathrm{mm})\end{array}$ & $\begin{array}{c}\text { Consis- } \\
\text { tency } \\
\text { class }\end{array}$ & $\begin{array}{c}\text { Porosity } \\
(\%)\end{array}$ & $\mathrm{pH}(-)$ & $\begin{array}{c}\text { Bulk } \\
\text { density } \\
(\mathrm{kg} / \mathrm{m})\end{array}$ \\
\hline Reference & 5.50 & $\mathrm{~S} 2$ & 1.50 & 12.56 & 2542.04 \\
\hline $5 w / \% \mathrm{SiC}$ & 13.00 & $\mathrm{~S} 3$ & 0.70 & 12.64 & 2583.72 \\
\hline $10 w / \% \mathrm{SiC}$ & 4.80 & $\mathrm{~S} 2$ & 0.90 & 12.66 & 2578.21 \\
\hline $15 w / \% \mathrm{SiC}$ & 6.00 & $\mathrm{~S} 2$ & 0.90 & 12.62 & 2591.44 \\
\hline
\end{tabular}

The results show that the three mixtures exhibit the same consistency class: S2. The mixture with the $5 \mathrm{w} / \%$ addition of silicon carbide had the S3 class. It is probably caused by an error during the preparation process of the mixture. The highest porosity was observed for the reference mixture $(1.5 \%)$. Small particles of silicon carbide decrease the volume of the pores to $0.7 \%$ for $5 \mathrm{w} / \%$ of $\mathrm{SiC}$. The $\mathrm{pH}$ value is similar for all mixtures and is equal $\approx 12.60$. Moreover, as the content of silicon carbide increase, an increasing effect of the sample weight was observed.

Table 2: Mechanical coefficients' comparison for the researched samples

\begin{tabular}{|c|c|c|}
\hline Recipe & $\begin{array}{c}\text { Young modulus } \\
(\mathrm{GPa})\end{array}$ & $\begin{array}{c}\text { Poisson coefficient } \\
(-)\end{array}$ \\
\hline Reference & 35.435 & 0.129 \\
\hline $5 w / \% \mathrm{SiC}$ & 35.561 & 0.130 \\
\hline $10 w / \% \mathrm{SiC}$ & 36.759 & 0.134 \\
\hline $15 w / \% \mathrm{SiC}$ & 37.346 & 0.135 \\
\hline
\end{tabular}




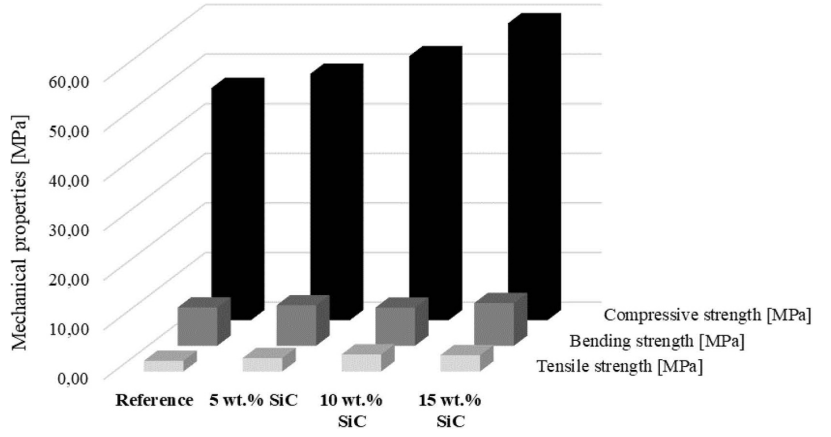

Figure 2: Mechanical properties of the investigated samples

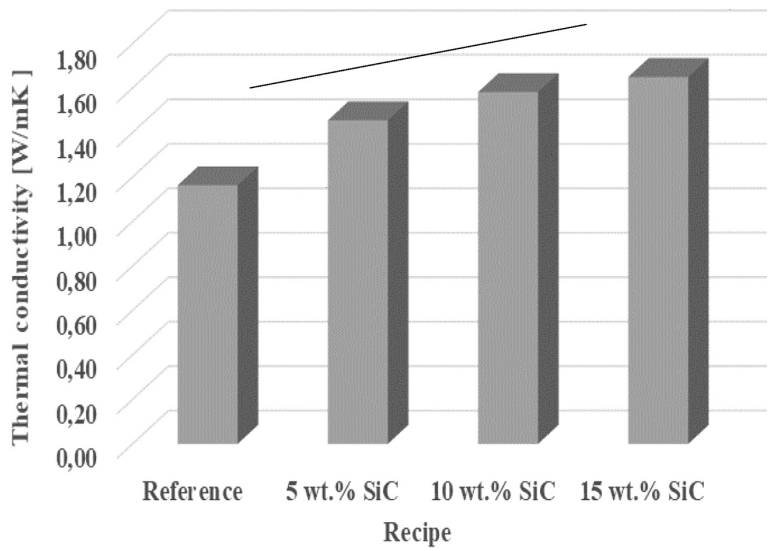

Figure 3: Thermal conductivity of characterized concrete with $\mathrm{SiC}$ addition

Table 3: Basic thermal properties of researched concrete samples

\begin{tabular}{|c|c|c|}
\hline Recipe & $\begin{array}{c}\text { Specific heat } \\
\left(\mathrm{J} / \mathrm{m}^{3} \mathrm{~K}\right)\end{array}$ & $\begin{array}{c}\text { Thermal diffusivity } \\
\left(\mathrm{m}^{2} / \mathrm{s}\right)\end{array}$ \\
\hline Reference & $1.36 \mathrm{E}+06$ & $1.01 \mathrm{E}-06$ \\
\hline $5 w / \% \mathrm{SiC}$ & $1.51 \mathrm{E}+06$ & $1.01 \mathrm{E}-06$ \\
\hline $10 w / \% \mathrm{SiC}$ & $1.53 \mathrm{E}+06$ & $8.62 \mathrm{E}-07$ \\
\hline $15 w / \% \mathrm{SiC}$ & $1.67 \mathrm{E}+06$ & $9.90 \mathrm{E}-07$ \\
\hline
\end{tabular}

The effect of the mechanical strength of the investigated samples is shown in Figure 2. Also, the mechani- cal coefficients were measured, calculated and presented in Table 2. The increased effect of the addition of the silicon carbide was observed. However, the very similar value of the bending strength of the reference and 10 w/\% were noted $(\approx 7.7 \mathrm{MPa})$. The recipe was calculated using the mechanical strength class of C30/37 (37 MPa). All the tested samples exhibit the higher value of mechanical strength compared with the design value, respectively: 46.80 $\mathrm{MPa}$, 49.66 $\mathrm{MPa}, 53.22 \mathrm{MPa}$ and $59.86 \mathrm{MPa}$. Furthermore, the addition of $15 \mathrm{w} / \%$ of SiC increased the final mechanical class of the concrete by four levels to $\mathrm{C} 50 / 60$. The mechanical coefficients depend on the mechanical strength and the same effect was obtained. A slight difference of the Poisson coefficient was noted. As the content of the silicon carbide increased, the coefficients are increasing. This phenomenon confirmed that the concrete sample was well-prepared for the mechanical strength testing process.

The basic thermal parameters were characterized and presented in Figure 3 and Table 3.

The new developed concrete samples revealed the increase of the thermal properties in all cases. The highest change in the thermal conductivity was observed. The reference sample exhibited $1.16 \mathrm{~W} / \mathrm{mK}$, but the sample with $15 w / \%$ of $\mathrm{SiC}$ addition exhibited $1.65 \mathrm{~W} / \mathrm{mK}$. In this case, a $20 \%$ increase in the thermal conductivity was observed. The thermal diffusivity was decreased, respectively, until $1.01 \mathrm{e}^{-6}$ for the reference and to $8.62 \mathrm{e}^{-7}$ for $10 w / \% \mathrm{SiC}$ addition. The best thermal properties for the $15 w / \%$ addition of silicon carbide was obtained and for this type of research the sample is the largest thermal conductor.

Light transmission-reflection microscope images in cross-section after the mechanical strength tests are shown in Figure 4.

The surface of the observed images do not show signs of poorly selected values of the vibration time and the mixing time. All the particles do not form agglomerates and are evenly distributed. No places were observed


Figure 4: LM images after the mechanical properties 
where the cement was not bonded to the rest of the additives. It can be seen that this is the sign of a well-prepared sample for all the tested cases.

\section{DISCUSSION}

In this work the results of a silicon carbide addition to the concrete matrix were summarized. The application of this kind of admixture obtained the highest values of mechanical strength and thermal properties of the investigated samples. The presented results shown that the admixture addition significantly increased the final physio-mechanical properties of the tested samples. Other authors showed similar properties. ${ }^{6,10-13}$ Silicon carbide is a very popular compound due its thermal properties. According to the new solution, silicon carbide is widely used in the production of building materials. The addition of $\mathrm{SiC}$ also caused an increase in the mechanical strength and thermal conductivity. In this work the authors added the largest value of silicon carbide (15 $w / \%$ of cement weight). An analysis of the results showed that the cement can be replaced by a new commercial filler as well, and the properties of the concrete sample increased. ${ }^{13-18}$ It is a very promising addition, because cement production is a very non-ecological process and requires a lot of energy consumption. This kind of admixturing provides the fabrication of ecological concrete with unusual properties. It was proven that the fabrication of a new concrete composite with the highest amount of admixtures is possible and did not require a special method of production. New synthesized commercial admixtures occurring on the international markets meet the requirements of new buildings technology in civil engineering. ${ }^{18-21}$

\section{CONCLUSIONS}

The goal of this research was to verify the influence of silicon carbide additions on the physio-chemical properties of new prepared concrete samples. Nowadays, new solutions are being sought for concrete admixtures for improving its final properties. Special building technologies are required to develop chip and widely available materials for concrete admixture. One of the solutions, for the thermal and high mechanical strength, is the use of silicon carbide. The designed recipe exhibits the highest mechanical strength and thermal properties compared with the reference sample without SiC. The obtained results show that the $\mathrm{SiC}$ addition increased the mechanical strength 4 levels up. The technology and prepared conditions are the same, and the silicon carbide does not need a special treatment in the process of fabrication for the final concrete elements. $\mathrm{SiC}$ can be used as a filler, admixture and aggregate on automatic line, handmade or prefabrication process. This study proved that silicon carbide as an admixture exhibits good mechanical and thermal properties and can by used as a special additive in civil engineering and military applications.

\section{Acknowledgment}

Financial support of Research Statutory Program financed from Military University of Technology, Faculty of Civil Engineering and Geodesy: "Research of materials and construction elements of military infrastructure special objects", No. 886/2019 is gratefully acknowledged.

\section{REFERENCES}

${ }^{1}$ A. Bahari, A. Sadeghi Nik, M. Roodbari E. Mirshafiei, B. Amiri, Effect of Silicon Carbide Nano Dispersion on the Mechanical and Nano Structural Properties of Cement, Natl. Acad. Sci. Lett., 38 (2015) 361-364, doi:10.1007/s40009-014-0316-6

${ }^{2}$ J. K. Choi, V. Fthenakis, Crystalline silicon photovoltaic recycling planning: macro and micro perspectives, J.Clea. Prod., 66 (2014) 1, 443-449, doi:10.1016/j.jclepro.2013.11.022

${ }^{3}$ G. Li D, P. F. Xing, Y. X. Zhuang, F Li, G. F. Tu, Recovery of high purity silicon from S0G crystalline silicon cutting slurry waste, Trans. Nonfer. Met. Soc. Chi., 24 (2014) 4, 1237-1241, doi:10.1016/j.jclepro.2013.11.022

${ }^{4}$ H. S. G. K. Murthy, Evolution and present status of silicon carbide slurry recovery in silicon wire sawing, Res., Conser. Rec., 104 (2015), 194-205, doi:10.1016/j.resconrec.2015.08.009

${ }^{5}$ Z. Jiang, Q. Ren, H. Li, Q. Chen, Silicon carbide waste as a source of mixture materials for cement mortar, Front. Environ. Sci. Eng., 11 (2017), 2, doi:10.1007/s11783-017-0974-y

${ }^{6}$ M. Małek, M. Jackowski, W. Życiński, M. Wachowski, Characterization of new filler additions affecting the mechanical strength of concrete, Mat. Tech., 53 (2019) 3, 399-403, doi:10.17222/mit.2018.155

${ }^{7}$ S. Gwon, S. Y. Jang, M. Shina, Microstructure evolution and strength development of ultra rapid hardening cement modified with redispersible polymer powder, Construction and Building Materials, 192 (2018), 715-730, doi:10.1016/j.conbuildmat.2018.10.178

${ }^{8}$ Y. J. Kim, A. Gaddafi, I. Yoshitake, Permeable concrete mixed with various admixtures, Mat. \& Des., 100 (2016), 110-119, doi:10.1016/ j.matdes.2016.03.109.

${ }^{9}$ J. Zhang, X. P. Ding, Q. Wang, X. Zheng, Effective solution for low shrinkage and low permeability of normal strength concrete using calcined zeolite particles, Con. and Build. Mat., 160 (2018), 57-65, doi:10.1016/j.conbuildmat.2017.11.029.

${ }^{10}$ P. Wiśniewski, M. Małek, J. Mizera, K. J. Kurzydłowski, Effect of adding water-based binders on the technological properties of ceramic slurries based on silicon carbide, Mat. Tech 51 (2017) 2, 225, doi:10.17222/mit.2015.194

${ }^{11}$ M. Malek, P. Wisniewski, J. Szymańska, J. Mizera, K. J. Kurzydlowski, Technological properties of ceramic slurries based on silicon carbide with poly(vinyl alcohol) addition for shell moluds fabrication in precision casting process, Act. Phys. Pol. A, 129 (2016) 4, 528-530, doi:10.12693/APhysPolA.129.528

${ }^{12}$ D. Zarzycka, P. Wisniewski, M. Malek J. Szymanska, J. Mizera, Investigation of the Basic Properties of Ceramic Proppants in Raw State Obtained by the Method of Mechanical Granulation, Act. Phys. Pol. A, 129 (2016) 4, 552-555, doi:10.12693/APhysPolA.129.552

${ }^{13}$ J. Szymańska, P. Wiśniewski, M. Małek, J. Mizera, K. J. Kurzydłowski, Investigation of key parameters influence on properties of the green pellents and lightweight ceramic proppants obtained by mechanical granulation method, J. Ther. Analy. Calor., 125 (2016) 3, 1411-1423, doi.org/10.1007/s10973-016-5704-3

${ }^{14}$ J. Szymańska, P. Wiśniewski, M. Małek, J. Mizera, Rheological properties of alumina ceramic slurries for ceramic shell moulds fabrication, Mat. Tech., 50 (2016) 5, 735-738, doi:10.17222/mit. 2015.188 
${ }^{15}$ T. Rudnicki, R. Jurczak. Recycling of a Concrete Pavement after over 80 Years in Service. Materials, 13(10), (2020), 2262, doi:10.3390/ma13102262

${ }^{16}$ Szcześniak, A.; Zychowicz, J.; Stolarski, A. Influence of Fly Ash Additive on the Properties of Concrete with Slag Cement. Materials, 13, (2020), 3265. doi:10.3390/ma13153265

${ }^{17} \mathrm{~T}$. Rudnicki. The method of aggregate skeleton in self compacting concrete designing with segment regression. CWB-1/2016, 10-19, (2016), doi:10.5281/zenodo.3739533

${ }^{18}$ A. Szcześniak, A. Stolarski, Dynamic Relaxation Method for Load Capacity Analysis of Reinforced Concrete Elements, Appl. Sci. 8, (2018) 3, 396, doi:10.3390/app8030396
${ }^{19}$ L. Akand, M. Yang, X. Wang, Effectiveness of chemical treatment on polypropylene fibers as reinforcement in pervious concrete, Const. Build. Mater., 163 (2018), 32-39

${ }^{20}$ R. Serrano, A. Cobo, M. I. Prieto, M. González, Analysis of fire resistance of concrete with polypropylene or steel fibers, Construction and Building Materials, 122 (2016), 302-309

${ }^{21}$ M. Szelagg, Evaluation of cracking patterns of cement paste containing polypropylene fibers, Composite Structures, 220 (2019), 402-411 